\title{
Listeria monocytogenes in Fresh Produce: Outbreaks, Prevalence and Contamination Levels
}

\author{
Qi Zhu, Ravi Gooneratne and Malik Altaf Hussain * \\ Department of Wine, Food and Molecular Biosciences, Lincoln University, Lincoln 7647, Canterbury, \\ New Zealand; Qi.Zhu@lincolnuni.ac.nz (Q.Z.); Ravi.Gooneratne@lincoln.ac.nz (R.G.) \\ * Correspondence: Malik.Hussain@lincoln.ac.nz; Tel.: +64-220-144-552
}

Academic Editor: Christopher J. Smith

Received: 19 October 2016; Accepted: 8 March 2017; Published: 9 March 2017

\begin{abstract}
Listeria monocytogenes, a member of the genus Listeria, is widely distributed in agricultural environments, such as soil, manure and water. This organism is a recognized foodborne pathogenic bacterium that causes many diseases, from mild gastroenteritis to severe blood and/or central nervous system infections, as well as abortion in pregnant women. Generally, processed ready-to-eat and cold-stored meat and dairy products are considered high-risk foods for L. monocytogenes infections that cause human illness (listeriosis). However, recently, several listeriosis outbreaks have been linked to fresh produce contamination around the world. Additionally, many studies have detected L. monocytogenes in fresh produce samples and even in some minimally processed vegetables. Thus L. monocytogenes may contaminate fresh produce if present in the growing environment (soil and water). Prevention of biofilm formation is an important control measure to reduce the prevalence and survival of L. monocytogenes in growing environments and on fresh produce. This article specifically focuses on fresh produce-associated listeriosis outbreaks, prevalence in growing environments, contamination levels of fresh produce, and associated fresh produce safety challenges.
\end{abstract}

Keywords: Listeria monocytogenes; fresh produce; foodborne pathogen; contamination; listeriosis

\section{Introduction}

Listeria monocytogenes, a member of the genus Listeria, naturally occurs in agricultural environments such as soil, manure and water [1]. Scientific literature frequently discusses the ability of this microorganism to survive in the food-processing and produce-packing environment and equipment [2]. It is a pathogenic bacterium that can cause a rare but dangerous infection called listeriosis. The severity of listeriosis can range from mild gastroenteritis to severe disease conditions (septicemia, encephalitis, meningitis, abortions and stillbirths) and can result in a high fatality rate in immune-compromised populations [3]. Some people have a higher risk for developing listeriosis, such as the elderly ( $>65$ years) [4-6], infants and toddlers ( $<5$ years) [4,7-9], pregnant women [3,8], and the unborn $[8,10]$. About $17 \%$ of listeriosis cases occur in pregnant women [10]. According to the FDA (Food and Drug Administration), about 2500 people suffer from listeriosis in the USA annually [10]. The mortality rate could be $20 \%-30 \%$ of those who contract listeriosis [3]. L. monocytogenes is responsible for $19 \%$ of the total deaths due to the consumption of contaminated food in the USA [11].

L. monocytogenes is commonly found and isolated from processed, ready-to-eat (RTE) and cold-stored meat and dairy products. An increasing number of recent reports show contamination and prevalence of L. monocytogenes in fresh produce. L. monocytogenes bacteria have been isolated from market or restaurant produce such as cabbage [12], corn [13], carrots [14-16], lettuce [17-23], cucumbers $[1,24,25]$, parsley $[11,26,27]$ and salad vegetables $[11,25,28,29]$. Outbreaks of L. monocytogenes infections associated with fresh produce have been reported in various parts of the world [24]. For example, L. monocytogenes was responsible for the deaths of 10 people in a food 
poisoning listeriosis outbreak in chopped celery in Texas in 2010 [30]; in 2011, 30 people were infected by listeria-contaminated melons in Colorado [31]; and in 2014, a listeria outbreak linked to caramel apple contamination was reported in California [5]. This trend has continued and prevention of Listeria contamination in fresh fruit and vegetables as well as fresh produce-associated listeriosis outbreaks is now a food safety challenge.

This article focuses on fresh produce-associated listeriosis outbreaks, prevalence and survival of L. monocytogenes in fresh produce growing environments, listeria contamination of produce and a brief note on measures that could be used to control or reduce the level of contamination.

\section{Foodborne Listeriosis}

It has been over 90 years since human and animal listeriosis was first recognized as an infection caused by a bacterium in the 1920s. The first conclusive link of L. monocytogenes to a foodborne outbreak in 1981 stimulated research and survey work to determine the ubiquity of the organism and its method of transmission [32]. L. monocytogenes gained recognition as a major foodborne pathogen when the mortality rate did not diminish over the following years, even though the number of cases seemed to be small compared with the estimated illnesses associated with salmonellosis and campylobacteriosis [33].

L. monocytogenes can cause two types of disease syndromes. Listeriosis is defined as being caused by invasive L. monocytogenes. That is, the organism usually infects sterile parts of the body, such as the liver [34], spleen [35], cerebral spinal fluid [36] and blood [37]. In healthy adults, diarrhea and fever are the main symptoms [38], in pregnant women it is fever, diarrhea, abortion or stillbirth [39], and in the newborn it can cause sepsis, pneumonia and meningitis [40-44]. L. monocytogenes can also cause a non-invasive disease, usually as a febrile gastroenteritis or non-invasive gastroenteritis, and it has been linked to outbreaks resulting from contaminated deli meat [45,46], chocolate milk [47], cheese [48-50], smoked fish [51,52] and corn [13].

Foodborne listeriosis is a relatively rare but serious disease with a high fatality rate (up to $30 \%$ ) compared with diseases caused by other foodborne microbial pathogens [2,11]. The incidence rate of foodborne outbreaks caused by contaminated fresh fruits and vegetables has shown an increasing trend in recent years [53]. Most outbreaks have been reported in the USA, Europe, Canada, and to a lesser extent in Australia and New Zealand [33].

\section{Fresh Produce-Associated Listeriosis Outbreaks}

In 1997, a serious Listeria outbreak associated with canned corn contaminated by L. monocytogenes occurred in two primary schools and a university in Italy. The main symptoms in this outbreak were febrile illness and gastroenteritis. A large number of people (2930 in total) developed febrile gastroenteritis in these three institutes, including primary school students aged six to 10 years, adult staff in the primary school, and students at the university. Investigation into this incident showed that the symptoms occurred after eating food supplied by the same caterer. No other cases were reported outside these three institutions in the same area during 1997 [13].

In 2010, the Texas Department of State Health Services (DSHS) reported a listeriosis outbreak linked to chopped celery. Of the 10 infected patients aged 56 to 93 years admitted to the hospital, five patients died within three months [30].

In 2011, an outbreak of listeriosis occurred in 28 different states in the US, caused by consumption of contaminated melons, in which a total of 147 persons were affected and 33 died. In this outbreak, an analysis of L. monocytogenes using pulsed-field gel electrophoresis (PFGE) matched the subtype of L. monocytogenes colonies isolated from samples of cut cantaloupe and from the patients' blood. A pregnant woman who was affected in this outbreak had a miscarriage [54]. In the same year, another outbreak associated with romaine lettuce was recorded across 19 states in the USA. In this outbreak, 84 became sick and of these, 15 died. The Federal Drug Agency (FDA) tested samples randomly from the True Leaf Farms of California. The results of microbiological analyses were positive for 
L. monocytogenes. Approximately 30,000 pounds of chopped and bagged romaine lettuce in 90 cartons were recalled [55].

A listeriosis outbreak associated with caramel apples occurred in December 2014 in the USA. The vehicle for this outbreak was pre-packaged caramel apples. Testing confirmed that the origin of this outbreak was from the firm's apple-packing facility. In total, 35 people, including 11 pregnant women, were infected by L. monocytogenes in 12 states. One of the infected pregnant women had a miscarriage. Seven out of the 35 people infected died during the outbreak [5]. More recently, a multistate outbreak of L. monocytogenes affected nine states in the USA in January 2016. Nineteen of the infected people were hospitalized, and one person from Michigan died of listeriosis. Epidemiological and laboratory evidence showed that packaged salads produced in Ohio were responsible for the outbreak. Table 1 below gives a summary of several outbreaks caused by fresh fruit and vegetables since 1979.

Table 1. Listeriosis outbreaks associated with fresh produce.

\begin{tabular}{|c|c|c|c|}
\hline Outbreak Location/Year & $\begin{array}{l}\text { Deaths/Cases } \\
\text { (\% Mortality) }\end{array}$ & Food Vehicle & References \\
\hline Boston, USA, 1979 & $3 / 20(15)$ & Raw vegetables & Ho et al. [56] \\
\hline Moncalieri and Giaveno, Italy, 1997 & $0 / 2930(0)$ & Corn & Aureli et al. [13] \\
\hline Texas, USA, 2010 & $5 / 10(50)$ & Chopped celery & Gaul et al. [30] \\
\hline Colorado, USA, 2011 & $33 / 147(22)$ & Whole cantaloupes & CDC [54] \\
\hline California, USA, 2014 & $1 / 32(3)$ & Caramel apples & $\mathrm{CDC}[5]$ \\
\hline Ohio, USA, 2016 & $1 / 19(5)$ & Packaged salads & CDC [50] \\
\hline
\end{tabular}

\section{Prevalence and Survival of L. monocytogenes in Produce Growing Environments}

L. monocytogenes is present in many animals and humans $[59,60]$, so it is possible to isolate the bacterium from the feces of these sources and in their environment [61-63]. Moreover, fresh produce and soil can be contaminated by sewage water applied as fertilizer to the crop plants [64]. Thus, L. monocytogenes can be recycled among vegetables, humans and soils contaminated with feces (Figure 1). This bacterium has an interesting life cycle adaptation capability. It lives a saprophytic life in the soil but can make the transition into a pathogenic life when it enters into human or animal cells [65]. The transition from a saprophyte to a cytosolic pathogen occurs through careful modulation of the activity of a specific regulatory protein (PrfA) and the type of available carbon source.

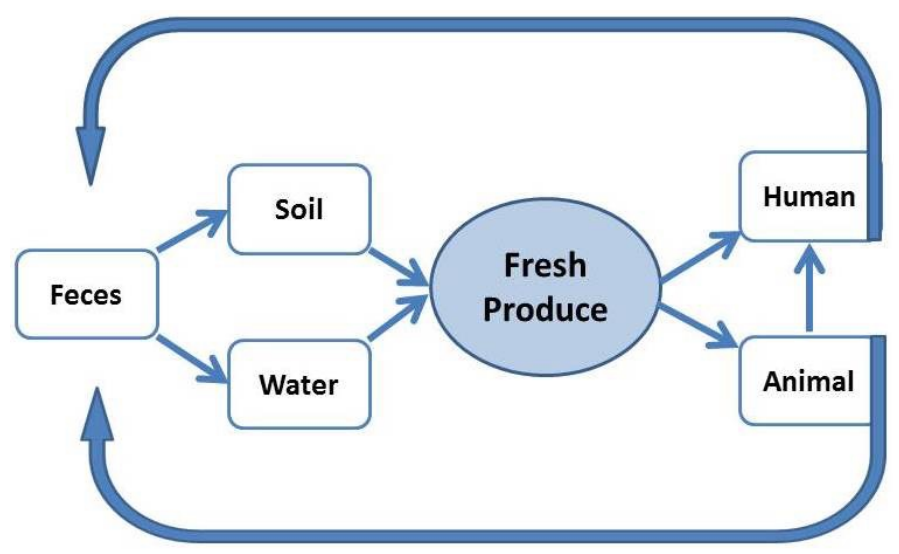

Figure 1. Potential pathways of L. monocytogenes transmission to humans via fresh produce.

L. monocytogenes has been isolated from RTE foods, such as freshly cut fruit [66] and fresh-cut vegetables [67]. Additionally, L. monocytogenes has been isolated from the vegetable growing environment [63]. Temperature, water activity $\left(\mathrm{a}_{\mathrm{w}}\right)$ and the $\mathrm{pH}$ of foods are the main factors 
that influence the multiplication and survival of L. monocytogenes. Technical reports describe that L. monocytogenes can grow under a wide range of growth conditions during food processing and storage, for example, at temperatures as low as $-0.4{ }^{\circ} \mathrm{C}$ [68] and over a wide range of $\mathrm{pH}$ values from 4.3 to 9.4 [69]. In the case of the contaminated melons from Jensen Farms in Colorado (2011), the temperature created an ideal environment for Listeria to grow. In addition, the equipment and machinery were impossible to fully clean, and therefore had dirt on them. In addition, the potato washing machine was used for washing cantaloupes. This resulted in the contamination of the cantaloupes. Furthermore, trucks, including those used to haul rejected cantaloupes sent to cattle feedlots, were parked next to the packing plant. This made it easy for the trucks to be contaminated with Listeria from the cattle farms [54].

As mentioned above, many factors influence the prevalence of L. monocytogenes in fresh produce, including direct or indirect contamination from the environment, such as from soil, water, compost and feces (Table 2). In one research project, 174 samples were tested for L. monocytogenes and 48 produced a positive reaction. All L. monocytogenes-positive water samples were from natural water sources such as creek and pond water, and none of the 28 samples from piped water and well water tested positive for L. monocytogenes [70]. A similar scenario was observed in an investigation into compost and irrigated water [71]. Szymczak et al. [72] conducted research on the prevalence of L. monocytogenes in fresh produce in relation to the type of soil, including those lands that were treated with natural fertilizers, artificial fertilizers, and also wastelands and garden plots. It was apparent that the artificial environment was more suitable for L. monocytogenes to survive. Exciting research on the factors (including temperature and moisture) that can influence the survival of L. monocytogenes in soil was carried out by McLaughlin et al. [73]. They used three marked colonies to monitor L. monocytogenes survival in different soil types. They found that L. monocytogenes can survive in normal soil, and that the bacterium preferred high-moisture-containing soils. In another research study, Locatelli et al. [74] showed that physical and chemical properties of soil influence the survival of L. monocytogenes. Both biotic and abiotic factors influence the survival of L. monocytogenes. So, it is quite clear that the external environment (contaminated soil, water and nutrient content, soil properties) affects the survival of L. monocytogenes. However, there could be other factors acting concurrently on L. monocytogenes survival, especially under moist conditions.

Table 2. Prevalence of L. monocytogenes in a fresh produce growing environment.

\begin{tabular}{|c|c|c|c|}
\hline Country & $\begin{array}{l}\text { Environment (Total } \\
\text { Number of Samples) }\end{array}$ & $\begin{array}{c}\text { Frequency }{ }^{\text {a }} \text { Number of } \\
\text { Positive Samples (\%) }\end{array}$ & References \\
\hline \multirow{6}{*}{ USA } & Soil (178) & $16(9 \%)$ & \multirow{6}{*}{ Strawn et al. [70] } \\
\hline & Drag swab (175) & $15(9 \%)$ & \\
\hline & Fecal (61) & $9(15 \%)$ & \\
\hline & Water (174) & $48(28 \%)$ & \\
\hline & Engineered (28) & $0(0 \%)$ & \\
\hline & Surface (146) & $48(33 \%)$ & \\
\hline \multirow{2}{*}{ USA } & Field & $263(17.5 \%)$ & \multirow{2}{*}{ Strawn et al. [71] } \\
\hline & Water & $74(30 \%)$ & \\
\hline Poland & Soil (1000) & $55(5.5 \%)$ & Szymczak et al. [72] \\
\hline Ireland & Soil & & McLaughlin et al. [73] \\
\hline French & soil & & Locatelli et al. [74] \\
\hline
\end{tabular}

\section{L. monocytogenes Contamination Level of Fresh Produce}

Contamination of fresh produce with pathogenic organisms affecting human health can occur at the pre-harvest or post-harvest stage. There are numerous direct or indirect sources of contamination, including animals or insects, soil, water, dirty equipment, and human handling. Many methods, such 
as the application of antimicrobial agents and UV radiation, have been used to reduce the microbial load in fresh produce. However, a pathogenic bacterium such as L. monocytogenes might not be completely inactivated due to its remarkable ability to survive in adverse conditions. In Table 3 , several studies are listed that illustrate the prevalence of L. monocytogenes in fresh produce. Szymczak et al. [72] showed that $5 \%$ of parsley grown in naturally fertilized soil was positive for L. monocytogenes. In addition, an assessment of lettuce for L. monocytogenes was undertaken from the farm to the table [18]. Results indicated that $1.05 \mathrm{log} \mathrm{cfu} / \mathrm{g}$ L. monocytogenes were found in samples from restaurants and $0.146 \mathrm{log} \mathrm{cfu} / \mathrm{g}$ in samples from homes. Although both these sets of samples had been treated before cooking or eating, samples from home treatments were cleaner than those from restaurants [18]. Similar studies showed that the washing of lettuce, cucumber and parsley markedly reduces the content of L. monocytogenes [75]. They also studied the influence of the storage temperature, water temperature, acetic acid concentration and immersion time on the survival of L. monocytogenes. As expected, the higher storage temperatures increased the number of L. monocytogenes colonies. Although washing with dilute acetic acid had some effect on reducing the number of L. monocytogenes, the extent of the reduction depended largely on the structure of the vegetable [75]. It is speculated that washing fresh produce to reduce the number of $L$. monocytogenes is more effective in fruits than it is in leafy vegetables.

Table 3. Some selected studies that reported the prevalence of L. monocytogenes in fresh produce.

\begin{tabular}{|c|c|c|c|}
\hline Produce & Country & Prevalence $^{a}$ & References \\
\hline Vegetables & China & $140(8,5.7 \%)$ & Wu et al. [76] \\
\hline \multirow{4}{*}{ Parsley } & Poland & $30(3,10.0 \%)$ & Szymczak et al. [72] \\
\hline & Malaysia & $16(4,25.0 \%)$ & Ponniah et al. [11] \\
\hline & Brazil & $22(1,4.5 \%)$ & Aparecida de Oliveira et al. [77] \\
\hline & Greece & & Nastou et al. [75] \\
\hline \multirow{2}{*}{ Collard greens } & Brazil & $30(1,3.3 \%)$ & Aparecida de Oliveira et al. [77] \\
\hline & Brazil & $24(1,4.2 \%)$ & Sant'Ana et al. [78] \\
\hline \multirow{4}{*}{ Lettuce } & Korea & & Ding et al. [18] \\
\hline & Brazil & $152(3,2.0 \%)$ & Sant'Ana et al. [78] \\
\hline & Nigeria & & Uzeh et al. [79] \\
\hline & Greece & & Nastou et al. [75] \\
\hline \multirow{4}{*}{ Cabbage } & Malaysia & $32(7,21.9 \%)$ & Ponniah et al. [11] \\
\hline & Brazil & $11(2,18.2 \%)$ & Sant'Ana et al. [78] \\
\hline & Nigeria & & Uzeh et al. [79] \\
\hline & New Zealand & & Zhu et al. [80] \\
\hline Spinach & Brazil & $11(1,9.1 \%)$ & Sant'Ana et al. [78] \\
\hline Carrot & Malaysia & $33(8,24.2 \%)$ & Ponniah et al. [11] \\
\hline Tomato & Malaysia & $32(7,21.9 \%)$ & Ponniah et al. [11] \\
\hline \multirow{2}{*}{ Cucumber } & Malaysia & $32(7,21.9 \%)$ & Ponniah et al. [11] \\
\hline & Greece & & Nastou et al. [75] \\
\hline Sprouts & Korean & $112(1,0.9 \%)$ & Seo et al. [81] \\
\hline
\end{tabular}

A survey of L. monocytogenes contamination was published on minimally treated leafy vegetables, including collard greens, cabbage, lettuce, Chinese cabbage, and arugula [77]. In total, this research study examined 162 minimally processed leafy samples. Of these, only six samples were confirmed for Listeria spp contamination and only three samples were confirmed as L. monocytogenes, and these were found in collard greens, bunched parsley and spring onions. Research on market vegetables [78] showed L. monocytogenes contamination in $3.1 \%$ of the samples. Five salad samples had counts between $1.0 \times 10^{1}$ and $2.6 \times 10^{2} \mathrm{cfu} / \mathrm{g}$. Among the minimally processed vegetable samples evaluated in South Korea, $0.3 \%$ of them tested positive in sprouts [81]. Uzeh et al. [79] tested many salad vegetables 
(lettuce, cabbages, carrots and cucumbers), and only cabbages and lettuce showed a positive reaction. Thus, although L. monocytogenes levels may decrease after treatment, some colonies could still survive.

\section{Prevention of Biofilm Formation to Reduce the Level of Contamination}

Besides the factors associated with the growing environment, bacterial biofilm formation is an important pathway for fresh produce contamination. Oliveira et al. [82] stated that the term biofilm refers to a sessile form of microbial life, characterized by adhesion of microorganisms to biotic or abiotic surfaces, with consequent production of extracellular polymeric substances.

Fresh produce comes into contact with many different kinds of surfaces at different temperatures during processing or transport, and according to a study by Bonsaglia et al. [83], these two factors influence the extent of L. monocytogenes biofilm formation. They compared L. monocytogenes biofilms growing on three kinds of touched surfaces, polystyrene, glass and stainless steel, at three different temperatures $\left(4,20\right.$ and $\left.35^{\circ} \mathrm{C}\right)$. The results showed that L. monocytogenes attaches more easily to hydrophilic surfaces (glass and stainless steel) than to hydrophobic surfaces (polystyrene). Higher temperatures and longer incubation times decreased the extent of adherence to surfaces, but the results were not significant.

Biofilms are produced by bacteria, including L. monocytogenes itself, to enhance their survival and spread. Therefore, disrupting the biofilm of L. monocytogenes is a practical method to reduce its survival. Botticella et al. [84] discussed the importance of biofilm formation in relation to the safety of fresh-cut produce. According to them, biofilm formation allows L. monocytogenes to persist for long periods of time in the food processing environment and thus represents a source of recurrent contamination and poses a food safety risk. Results reported by Sant'Ana et al. [78] indicated that L. monocytogenes persistence either in the field or in the processing environment of the tested RTE vegetables was due to the presence of harborage sites due to biofilm formation. The most common methods employed to reduce biofilm formation include physical (such as UV-C) and chemical (such as chlorine dioxide, peroxyacetic acid) processes.

According to a recent study, physical methods are more effective in controlling biofilm formation because of their minimal influence on product quality and stability [85]. These authors used three physical methods to treat L. monocytogenes biofilms: $32 \mathrm{~Hz}$ ultra-sonication (US), $390 \mathrm{~mJ} / \mathrm{cm}^{2}$ Ultraviolet-C (UV-C), and $750 \mathrm{~mJ} / \mathrm{cm}^{2}$ cold oxygen plasma (COP). UV-C and COP were more effective in reducing L. monocytogenes biofilm formation. Another effective method to reduce L. monocytogenes biofilm production is to use organic acids combined with modified atmosphere packaging [86]. In that study, by Bae et al. [86], cabbages were treated with $2 \%$ lactic acid for 10 min combined with modified atmosphere packaging, and the number of L. monocytogenes were reduced by half (from $6.2 \mathrm{cfu} / \mathrm{g}$ to $3.1 \mathrm{cfu} / \mathrm{g}$ ). In addition, the modified atmosphere packaging (air, $\mathrm{N}_{2}$ gas, $\mathrm{CO}_{2}$ gas) proved to be effective in delaying the growth of L. monocytogenes.

\section{Conclusions}

L. monocytogenes is widely present in agricultural production environments, and it is implicated in the contamination of fresh crop produce. Most recent listeriosis outbreaks associated with fresh produce are attributed to the crop growing environment, post-harvest processing and retailing. Several reports have demonstrated that $L$. monocytogenes is commonly present in a wide variety of fresh produce samples. It is important to reduce the level of this pathogen to enhance the fresh produce safety and protect consumer health. Preventing L. monocytogenes biofilm formation through a practicable and effective method will help to decrease its survival and contamination levels in fresh produce.

Acknowledgments: This study was carried out with the financial support of the Faculty of Agriculture and Life Sciences, Lincoln University, Lincoln 7647, Canterbury, New Zealand.

Conflicts of Interest: The authors declare no conflict of interest. 


\section{References}

1. Jeyaletchumi, P.; Tunung, R.; Selina, P.M.; Chai, L.C.; Radu, S.; Farinazleen, M.G.; Cheah, Y.K.; Mitsuaki, N.; Yoshitsugu, N.; Kumar, M.P. Assessment of Listeria monocytogenes in salad vegetables through kitchen simulation study. J. Trop. Agric. Food Sci. 2012, 40, 55-62.

2. Azizoglu, R.A.; Gorski, L.; Kathariou, S. Listeria and produce: A troublesome liaison! Available online: http:/ / www.newfoodmagazine.com/advent-calendar/listeria-and-produce/ (accessed on 10 February 2017).

3. Swaminathan, B.; Gerner-Smidt, P. The epidemiology of human listeriosis. Microb. Infect. 2007, 9, $1236-1243$. [CrossRef] [PubMed]

4. Okutani, A.; Okada, Y.; Yamamoto, S.; Igimi, S. Nationwide survey of human Listeria monocytogenes infection in Japan. Epidemiol. Infect. 2004, 132, 769-772. [CrossRef] [PubMed]

5. CDC. Multistate Outbreak of Listeriosis Linked to Commercially Produced, Prepackaged Caramel Apples. 2015. Available online: http:/ /www.cdc.gov/listeria/outbreaks/caramel-apples-12--14/index.html (accessed on 15 October 2015).

6. Gillespie, I.A.; Mook, P.; Little, C.L.; Grant, K.; Adak, G.K. Listeria monocytogenes Infection in the Over-60s in England Between 2005 and 2008: A Retrospective Case-Control Study Utilizing Market Research Panel Data. Foodborne Pathog. Dis. 2010, 7, 1373-1379. [CrossRef] [PubMed]

7. Buzby, J.C. Children and Microbial Foodborne Illness. Food Rev. 2001, 24, 32.

8. Smith, B.; Kemp, M.; Ethelberg, S.; Schiellerup, P.; Bruun, B.G.; Gerner-Smidt, P.; Christensen, J.J. Listeria monocytogenes: Maternal-foetal infections in Denmark 1994-2005. Scand. J. Infect. Dis. 2009, 41, 21-25. [CrossRef] [PubMed]

9. Dilber, E.; Aksoy, A.; Çakir, M.; Bahat, E.; Kamaşak, T.; Dilber, B. Listeria monocytogenes meningitis in two immunocompetent children. Ann. Trop. Paediatr. 2009, 29, 225-229. [CrossRef] [PubMed]

10. FDA. Food Safety for Pregnant Women. 2011. Available online: http://www.fda.gov/food/ foodborneillnesscontaminants/peopleatrisk/ucm312704.htm (accessed on 27 November 2015).

11. Scallan, E.; Hoekstra, R.M.; Angulo, F.J.; Tauxe, R.V.; Widdowson, M.A.; Roy, S.L.; Jones, J.L.; Griffin, P.M. Foodborne illness acquired in the United States-Major pathogens. Emerg. Infect. Dis. 2011, 17, 7-15. [CrossRef] [PubMed]

12. Ponniah, J.; Robin, T.; Paie, M.S.; Radu, S.; Ghazali, F.M.; Kqueen, C.Y.; Nishibuchi, M.; Nakaguchi, Y.; Malakar, P.K. Listeria monocytogenes in raw salad vegetables sold at retail level in Malaysia. Food Cont. 2010, 21, 774-778. [CrossRef]

13. Aureli, P.; Fiorucci, G.C.; Caroli, D.; Marchiaro, G.; Novara, O.; Leone, L.; Salmaso, S. An Outbreak of Febrile Gastroenteritis Associated with Corn Contaminated by Listeria monocytogenes. N. Engl. J. Med. 2000, 342, 1236-1241. [CrossRef] [PubMed]

14. Ruiz-Cruz, S.; Acedo-Félix, E.; Díaz-Cinco, M.; Islas-Osuna, M.A.; González-Aguilar, G.A. Efficacy of sanitizers in reducing Escherichia coli O157:H7, Salmonella spp. and Listeria monocytogenes populations on fresh-cut carrots. Food Cont. 2007, 18, 1383-1390. [CrossRef]

15. Sy, K.V.; Murray, M.B.; Harrison, M.D.; Beuchat, L.R. Evaluation of Gaseous Chlorine Dioxide as a Sanitizer for Killing Salmonella, Escherichia coli O157:H7, Listeria monocytogenes, and Yeasts and Molds on Fresh and Fresh-Cut Produce. J. Food Prot. 2005, 68, 1176-1187. [CrossRef] [PubMed]

16. Kamat, A.; Ghadge, N.; Ramamurthy, M.; Alur, M. Effect of low-dose irradiation on shelf life and microbiological safety of sliced carrot. J. Sci. Food Agric. 2005, 85, 2213-2219. [CrossRef]

17. Thunberg, R.L.; Tran, T.T.; Bennett, R.W.; Matthews, R.N.; Belay, N. Microbial Evaluation of Selected Fresh Produce Obtained at Retail Markets. J. Food Prot. 2002, 65, 677-682. [CrossRef] [PubMed]

18. Ding, T.; Iwahori, J.; Kasuga, F.; Wang, J.; Forghani, F.; Park, M.-S.; Oh, D.-H. Risk assessment for Listeria monocytogenes on lettuce from farm to table in Korea. Food Control 2013, 30, 190-199. [CrossRef]

19. Althaus, D.; Hofer, E.; Corti, S.; Julmi, A.; Stephan, R. Bacteriological Survey of Ready-to-Eat Lettuce, Fresh-Cut Fruit, and Sprouts Collected from the Swiss Market. J. Food Prot. 2012, 75, 1338-1341. [CrossRef] [PubMed]

20. Francis, G.A.; O'Beirne, D. Isolation and Pulsed-Field Gel Electrophoresis Typing of Listeria monocytogenes from Modified Atmosphere Packaged Fresh-Cut Vegetables Collected in Ireland. J. Food Prot. 2006, 69, 2524-2528. [CrossRef] [PubMed] 
21. Abadias, M.; Usall, J.; Anguera, M.; Solsona, C.; Viñas, I. Microbiological quality of fresh, minimally-processed fruit and vegetables, and sprouts from retail establishments. Int. J. Food Microbiol. 2008, 123, 121-129. [CrossRef] [PubMed]

22. Soriano, J.M.; Rico, H.; Moltó, J.C.; Mañes, J. Listeria Species in Raw and Ready-to-Eat Foods from Restaurants. J. Food Prot. 2001, 64, 551-553. [CrossRef] [PubMed]

23. Johannessen, G.S.; Loncarevic, S.; Kruse, H. Bacteriological analysis of fresh produce in Norway. Int. J. Food Microbiol. 2002, 77, 199-204. [CrossRef]

24. Meldrum, R.J.; Little, C.L.; Sagoo, S.; Mithani, V.; McLauchlin, J.; de Pinna, E. Assessment of the microbiological safety of salad vegetables and sauces from kebab take-away restaurants in the United Kingdom. Food Microbiol. 2009, 26, 573-577. [CrossRef] [PubMed]

25. Jamali, H.; Paydar, M.; Chung, C.Y.; Wong, W.F. Prevalence of Listeria species and Listeria monocytogenes serotypes in ready mayonnaise salads and salad vegetables in Iran. Afr. J. Microbiol. Res. 2013, 7, 1903-1906.

26. Gómez-Govea, M.; Solís-Soto, L.; Heredia, N.; García, S.; Moreno, G.; Tovar, O.; Isunza, G. Analysis of microbial contamination levels of fruits and vegetables at retail in Monterrey, Mexico. J. Food Agric. Environ. 2012, 10, 152-156.

27. Öktem, A.B.; Bayram, G.; Ceylan, A.E.; Yentür, G. Prevalence of Listeria monocytogenes in Some Turkish Foodstuffs. J. Food Qual. 2006, 29, 76-86. [CrossRef]

28. Easa, S.M.H. Microorganisms found in fast and traditional fast food. J. Am. Sci. 2010, 6, 515-537.

29. Skalina, L.; Nikolajeva, V. Growth potential of Listeria monocytogenes strains in mixed ready-to-eat salads. Int. J. Food Microbiol. 2010, 144, 317-321. [CrossRef] [PubMed]

30. Gaul, L.K.; Farag, N.H.; Shim, T.; Kingsley, M.A.; Silk, B.J.; Hyytia-Trees, E. Hospital-Acquired Listeriosis Outbreak Caused by Contaminated Diced Celery-Texas, 2010. Clin. Infect. Dis. 2013, 56, 20-26. [CrossRef] [PubMed]

31. CDC. Multistate Outbreak of Listeriosis Linked to Whole Cantaloupes from Jensen Farms, Colorado. 2011. Available online: http://www.cdc.gov/listeria/outbreaks/cantaloupes-jensen-farms/ (accessed on 15 January 2016).

32. Liu, D. Handbook of Listeria monocytogenes; CRC Press: Boca Raton, FL, USA, 2008.

33. Todd, E.C.D.; Notermans, S. Surveillance of listeriosis and its causative pathogen, Listeria monocytogenes. Food Cont. 2011, 22, 1484-1490. [CrossRef]

34. Wing, E.J.; Gregory, S.H. Listeria monocytogenes: Clinical and Experimental Update. J. Infect. Dis. 2002, 185, S18-S24. [CrossRef] [PubMed]

35. Aoshi, T.; Carrero, J.A.; Konjufca, V.; Koide, Y.; Unanue, E.R.; Miller, M.J. The cellular niche of Listeria monocytogenes infection changes rapidly in the spleen. Eur. J. Immunol. 2009, 39, 417-425. [CrossRef] [PubMed]

36. Cone, L.A.; Leung, M.M.; Byrd, R.G.; Annunziata, G.M.; Lam, R.Y.; Herman, B.K. Multiple cerebral abscesses because of Listeria monocytogenes: Three case reports and a literature review of supratentorial listerial brain abscess(es). Surg. Neurol. 2003, 59, 320-328. [CrossRef]

37. Bhat, S.A.; Willayat, M.M.; Roy, S.S.; Bhat, M.A.; Shah, S.N.; Ahmed, A.; Maqbool, S.; Ganayi, B.A. Isolation, molecular detection and antibiogram of Listeria monocytogenes from human clinical cases and fish of Kashmir, India. Comp. Clin. Pathol. 2012, 22, 661-665. [CrossRef]

38. Salazar, J.K.; Wu, Z.; Yang, W.; Freitag, N.E.; Tortorello, M.L.; Wang, H.; Zhang, W. Roles of a Novel Crp/Fnr Family Transcription Factor Lmo0753 in Soil Survival, Biofilm Production and Surface Attachment to Fresh Produce of Listeria monocytogenes. PLoS ONE 2013, 8, e75736. [CrossRef] [PubMed]

39. Pérez-Trallero, E.; Zigorraga, C.; Artieda, J.; Alkorta, M.; Marimón, J.M. Two Outbreaks of Listeria monocytogenes Infection, Northern Spain. Emerg. Infect. Dis. 2014, 20, 2155-2157. [CrossRef] [PubMed]

40. Khoury, N.T.; Hossain, M.M.; Wootton, S.H.; Salazar, L.; Hasbun, R. Meningitis With a Negative Cerebrospinal Fluid Gram Stain in Adults: Risk Classification for an Adverse Clinical Outcome. Mayo Clin. Proc. 2012, 87, 1181-1188. [CrossRef] [PubMed]

41. Brouwer, M.C.; van de Beek, D.; Heckenberg, S.G.B.; Spanjaard, L.; de Gans, J. Community-Acquired Listeria monocytogenes Meningitis in Adults. Clin. Infect. Dis. 2006, 43, 1233-1238. [CrossRef] [PubMed]

42. Okike, I.O.; Lamont, R.F.; Heath, P.T. Do We Really Need to Worry About Listeria in Newborn Infants? Pediatr. Infect. Dis. J. 2013, 32, 405-406. [CrossRef] [PubMed] 
43. Gaschignard, J.; Levy, C.; Romain, O.; Cohen, R.; Bingen, E.; Aujard, Y.; Boileau, P. Neonatal Bacterial Meningitis: 444 Cases in 7 Years. Pediatr. Infect. Dis. J. 2011, 30, 212-217. [CrossRef] [PubMed]

44. Camacho-Gonzalez, A.; Spearman, P.W.; Stoll, B.J. Neonatal Infectious Diseases: Evaluation of Neonatal Sepsis. Pediatr. Clin. North Am. 2013, 60, 367-389. [CrossRef] [PubMed]

45. Lin, C.-M.; Takeuchi, K.; Zhang, L.; Dohm, C.B.; Meyer, J.D.; Hall, P.A.; Doyle, M.P. Cross-Contamination between Processing Equipment and Deli Meats by Listeria monocytogenes. J. Food Prot. 2006, 69, 71-79. [CrossRef] [PubMed]

46. Gottlieb, S.L.; Newbern, E.C.; Griffin, P.M.; Graves, L.M.; Hoekstra, R.M.; Baker, N.L.; Hunter, S.B.; Holt, K.G.; Ramsey, F.; Head, M.; et al. Multistate Outbreak of Listeriosis Linked to Turkey Deli Meat and Subsequent Changes in US Regulatory Policy. Clin. Infect. Dis. 2006, 42, 29-36. [CrossRef] [PubMed]

47. Proctor, M.E.; Brosch, R.; Mellen, J.W.; Garrett, L.A.; Kaspar, C.W.; Luchansky, J.B. Use of pulsed-field gel electrophoresis to link sporadic cases of invasive listeriosis with recalled chocolate milk. Appl. Environ. Microbiol. 1995, 61, 3177-3179. [PubMed]

48. CDC. Multistate Outbreak of Listeriosis Linked to Roos Foods Dairy Products. Available online: http:/ / www.cdc.gov/listeria/outbreaks/cheese-02--14/index.html (accessed on 4 February 2015).

49. CDC. Listeriosis Infections Linked to Marte Brand Frescolina Ricotta Salata Cheese. Available online: http:/ /www.cdc.gov/listeria/outbreaks/cheese-09--12/index.html (accessed on 4 February 2015).

50. CDC. Multistate Outbreak of Listeriosis Linked to Packaged Salads Produced at Springfield, Ohio Dole Processing Facility (Final Update). Available online: http://www.cdc.gov/listeria/outbreaks/baggedsalads-01--16/ (accessed on 15 August 2016).

51. Tham, W.; Ericsson, H.; Loncarevic, S.; Unnerstad, H.; Danielsson-Tham, M.-L. Lessons from an outbreak of listeriosis related to vacuum-packed gravad and cold-smoked fish. Int. J. Food Microbiol. 2000, 62, 173-175. [CrossRef]

52. Rørvik, L.M. Listeria monocytogenes in the smoked salmon industry. Int. J. Food Microbiol. 2000, 62, $183-190$. [CrossRef]

53. Mukherjee, A.; Speh, D.; Jones, A.T.; Buesing, K.M.; Diez-Gonzalez, F. Longitudinal microbiological survey of fresh produce grown by farmers in the upper Midwest. J. Food Prot. 2006, 69, 1928-1936. [CrossRef] [PubMed]

54. CDC. Listeria outbreaks. Available online: https://www.cdc.gov/listeria/outbreaks/ (accessed on 25 September 2016).

55. Shrivastava, S. Listeria Outbreak-Bacteria Found in Romaine Lettuce: FDA. Available online: http:/ / www. ibtimes.com/listeria-outbreak-bacteria-found-romaine-lettuce-fda-320544 (accessed on 14 March 2016).

56. Ho, J.L.; Shands, K.N.; Friedland, G.; Eckind, P.; Fraser, D.W. An outbreak of type 4b Listeria monocytogenes infection involving patients from eight boston hospitals. Arch. Intern. Med. 1986, 146, 520-524. [CrossRef] [PubMed]

57. Schlech, W.F.; Lavigne, P.M.; Bortolussi, R.A.; Allen, A.C.; Haldane, E.V.; Wort, A.J.; Hightower, A.W.; Johnson, S.E.; King, S.H.; Nicholls, E.S.; et al. Epidemic Listeriosis — Evidence for Transmission by Food. N. Engl. J. Med. 1983, 308, 203-206. [CrossRef] [PubMed]

58. Garner, D.; Kathariou, S. Fresh produce-associated listeriosis outbreaks, sources of concern, teachable moments, and insights. J. Food. Prot. 2016, 79, 337-344. [CrossRef] [PubMed]

59. Vela, A.I.; Fernandez-Garayzabal, J.F.; Vazquez, J.A.; Latre, M.V.; Blanco, M.M.; Moreno, M.A.; de la Fuente, L.; Marco, J.; Franco, C.; Cepeda, A.; et al. Molecular Typing by Pulsed-Field Gel Electrophoresis of Spanish Animal and Human Listeria monocytogenes Isolates. Appl. Environ. Microbiol. 2001, 67, 5840-5843. [CrossRef] [PubMed]

60. Srinivasan, V.; Nam, H.M.; Nguyen, L.T.; Tamilselvam, B.; Murinda, S.E.; Oliver, S.P. Prevalence of Antimicrobial Resistance Genes in Listeria monocytogenes Isolated from Dairy Farms. Foodborne Pathog. Dis. 2005, 2, 201-211. [CrossRef] [PubMed]

61. Olier, M.; Pierre, F.; Lemaître, J.-P.; Divies, C.; Rousset, A.; Guzzo, J. Assessment of the pathogenic potential of two Listeria monocytogenes human faecal carriage isolates. Microbiology 2002, 148, 1855-1862. [CrossRef] [PubMed]

62. Nightingale, K.K.; Schukken, Y.H.; Nightingale, C.R.; Fortes, E.D.; Ho, A.J.; Her, Z.; Grohn, Y.T.; McDonough, P.L.; Wiedmann, M. Ecology and Transmission of Listeria monocytogenes Infecting Ruminants and in the Farm Environment. Appl. Environ. Microbiol. 2004, 70, 4458-4467. [CrossRef] [PubMed] 
63. Esteban, J.I.; Oporto, B.; Aduriz, G.; Juste, R.A.; Hurtado, A. Faecal shedding and strain diversity of Listeria monocytogenes in healthy ruminants and swine in Northern Spain. BMC Vet. Res. 2009, 5, 2. [CrossRef] [PubMed]

64. Food Safety Authority of Ireland. The Control and Management of Listeria monocytogenes Contamination of Food; Food Safety Authority of Ireland: Dublin, Ireland, 2005.

65. Freitag, N.E.; Port, G.C.; Miner, M.D. Listeria monocytogenes-From saprophyte to intracellular pathogen. Nat. Rev. Microbiol. 2009, 7, 623-628. [CrossRef] [PubMed]

66. Oliveira, M.; Viñas, I.; Colàs, P.; Anguera, M.; Usall, J.; Abadias, M. Effectiveness of a bacteriophage in reducing Listeria monocytogenes on fresh-cut fruits and fruit juices. Food Microbiol. 2014, 38, 137-142. [CrossRef] [PubMed]

67. Vandamm, J.P.; Li, D.; Harris, L.J.; Schaffner, D.W.; Danyluk, M.D. Fate of Escherichia coli O157:H7, Listeria monocytogenes, and Salmonella on fresh-cut celery. Food Microbiol. 2013, 34, 151-157. [CrossRef] [PubMed]

68. Junttila, J.R.; Niemelä, S.I.; Hirn, J. Minimum growth temperature of Listeria monocytogenes and non-haemolytic listeria. J. Appl. Bacteriol. 1988, 65, 321-327. [CrossRef] [PubMed]

69. Te Giffel, M.C.; Zwietering, M.H. Validation of predictive models describing the growth of Listeria monocytogenes. Int. J. Food Microbiol. 1999, 46, 135-149. [CrossRef]

70. Strawn, L.K.; Fortes, E.D.; Bihn, E.A.; Nightingale, K.K.; Gröhn, Y.T.; Worobo, R.W.; Wiedmann, M.; Bergholz, P.W. Landscape and Meteorological Factors Affecting Prevalence of Three Food-Borne Pathogens in Fruit and Vegetable Farms. Appl. Environ. Microbiol. 2013, 79, 588-600. [CrossRef] [PubMed]

71. Strawn, L.K.; Gröhn, Y.T.; Warchocki, S.; Worobo, R.W.; Bihn, E.A.; Wiedmann, M. Risk Factors Associated with Salmonella and Listeria monocytogenes Contamination of Produce Fields. Appl. Environ. Microbiol. 2013, 79, 7618-7627. [CrossRef] [PubMed]

72. Szymczak, B.; Szymczak, M.; Sawicki, W.; Dabrowski, W. Anthropogenic impact on the presence of L. monocytogenes in soil, fruits, and vegetables. Folia Microbiol Praha 2014, 59, 23-29. [CrossRef] [PubMed]

73. McLaughlin, H.P.; Casey, P.G.; Cotter, J.; Gahan, C.G.M.; Hill, C. Factors affecting survival of Listeria monocytogenes and Listeria innocua in soil samples. Arch. Microbiol. 2011, 193, 775-785. [CrossRef] [PubMed]

74. Locatelli, A.; Spor, A.; Jolivet, C.; Piveteau, P.; Hartmann, A. Biotic and Abiotic Soil Properties Influence Survival of Listeria monocytogenes in Soil. PLoS ONE 2013, 8, e75969. [CrossRef] [PubMed]

75. Nastou, A.; Rhoades, J.; Smirniotis, P.; Makri, I.; Kontominas, M.; Likotrafiti, E. Efficacy of household washing treatments for the control of Listeria monocytogenes on salad vegetables. Int. J. Food Microbiol. 2012, 159, 247-253. [CrossRef] [PubMed]

76. Wu, S.; W, Q.; Zhang, J.; Chen, M.; Yan, Z.; Hu, H. Listeria monocytogenes prevalence and characteristics in retails raw foods in China. PLoS ONE 2015, 10, e0136682. [CrossRef] [PubMed]

77. Aparecida, O.M.; Abeid Ribeiro, E.G.; Morato Bergamini, A.M.; Pereira De Martinis, E.C. Quantification of Listeria monocytogenes in minimally processed leafy vegetables using a combined method based on enrichment and 16S rRNA real-time PCR. Food Microbiol. 2010, 27, 19-23. [CrossRef] [PubMed]

78. Sant'Ana, A.S.; Igarashi, M.C.; Landgraf, M.; Destro, M.T.; Franco, B.D.G.M. Prevalence, populations and pheno- and genotypic characteristics of Listeria monocytogenes isolated from ready-to-eat vegetables marketed in São Paulo, Brazil. Int. J. Food Microbiol. 2012, 155, 1-9. [CrossRef] [PubMed]

79. Uzeh, R.; Adepoju, A. Incidence and survival of Escherichia coli O157: H7 and Listeria monocytogenes on salad vegetables. Int. Food Res. J. 2013, 20, 1921-1925.

80. Zhu, Q.; Hussain, M.A. Prevalence of Listeria species in fresh salad vegetables and ready-to-eat foods containing fresh produce marketed in canterbury, New Zealand. Adv. Food Technol. Nutr. Sci. Open J. 2014, 1, 5-9. [CrossRef]

81. Seo, Y.-H.; Jang, J.-H.; Moon, K.-D. Microbial evaluation of minimally processed vegetables and sprouts produced in Seoul, Korea. Food Sci. Biotechnol. 2010, 19, 1283-1288. [CrossRef]

82. de Oliveira, M.M.M.; Brugnera, D.F.; Alves, E.; Piccoli, R.H. Biofilm formation by Listeria monocytogenes on stainless steel surface and biotransfer potential. Braz. J. Microbiol. 2010, 41, 97-106. [CrossRef] [PubMed]

83. Bonsaglia, E.C.R.; Silva, N.C.C.; Fernades Júnior, A.; Araújo Júnior, J.P.; Tsunemi, M.H.; Rall, V.L.M. Production of biofilm by Listeria monocytogenes in different materials and temperatures. Food Cont. 2014, 35, 386-391. [CrossRef] 
84. Botticella, G.; Russo, R.; Capozzi, V.; Amado, M.L.; Massa, S.; Spano, G.; Beneduce, L. Listeria monocytogenes, biofilm formation and fresh cut produce. 2013. Available online: http://www.formatex.info/microbiology4/ vol1/114-123.pdf (accessed on 5 February 2017).

85. Srey, S.; Park, S.Y.; Jahid, I.K.; Ha, S.-D. Reduction effect of the selected chemical and physical treatments to reduce L. monocytogenes biofilms formed on lettuce and cabbage. Food Res. Int. 2014, 62, 484-491. [CrossRef]

86. Bae, Y.-M.; Choi, N.-Y.; Heu, S.; Kang, D.-H.; Lee, S.-Y. Inhibitory effects of organic acids combined with modified atmosphere packaging on foodborne pathogens on cabbage. J. Korean Soc. Appl. Biol. Chem. 2011, 54, 993-997. [CrossRef]

(C) 2017 by the authors. Licensee MDPI, Basel, Switzerland. This article is an open access article distributed under the terms and conditions of the Creative Commons Attribution (CC BY) license (http://creativecommons.org/licenses/by/4.0/). 